\title{
PEMBELAJARAN BERBASIS STUDENT-CENTERED LEARNING DI PERGURUAN TINGGI: Suatu Tinjauan di UIN Sunan Kalijaga Yogyakarta
}

\author{
M. Arif Kurniawan ${ }^{1}$, Agus Miftahillah ${ }^{2}$, Nilna Milhatan Nasihah ${ }^{3}$ \\ 1,2,3Pascasarjana UIN Sunan Kalijaga Yogyakarta \\ 1,2,3Jl. Marsda Adi Sucipto, Yogyakarta
}

Email: muchamadarif28@gmail.com¹, ahilmiftah@gmail.com², nilnamilha@gmail.com³

\begin{abstract}
Abstrak:
Penelitian ini bertujuan untuk membandingkan pendekatan student-centered learning (SCL) di perguruan tinggi pada proses pembelajaran di tiga jurusan yang berbeda yaitu jurusan sosiologi, filsafat agama dan pendidikan bahasa Arab di UIN Sunan Kalijaga Yogyakarta. Ada dua permasalahan pokok dalam penelitian ini yakni bagaimana proses pembelajarannya serta apa strategi pembelajaran yang digunakan pada tiga jurusan tersebut. Metode yang digunakan dalam penelitian ini adalah metode deskriptif dengan pendekatan kualitatif. Hasil dari penelitian ini menunjukkan bahwa proses pembelajaran pada mata kuliah metodologi penelitian di jurusan sosiologi, mata kuliah filsafat India di jurusan filsafat agama dan mata kuliah bahasa Arab di jurusan pendidikan bahasa Arab telah menggunakan pendekatan SCL, meskipun proses pembelajaran dari ketiga jurusan itu menggunakan strategi yang berbeda. Strategi pembelajaran pada mata kuliah metodologi penelitian di jurusan sosiologi menggunakan strategi pembelajaran interaktif dan pengajaran terbimbing (guided teaching), jurusan filsafat agama pada mata kuliah filsafat India mengunakan strategi pembelajaran interaktif, lebih menekankan pada diskusi dan sharing diantara peserta didik, sedangkan di jurusan pendidikan bahasa Arab pada mata kuliah bahasa Arab menggunakan strategi pembelajaran peer lesson yaitu pembelajaran dengan cara mengajar sesama teman.
\end{abstract}

\begin{abstract}
:
This research aimed at comparing student-centered learning (SCL) Approach in the university in three different courses in three departments at UIN Sunan Kalijaga Yogyakarta. There were two main problems in this research. They were how was the learning process and what strategy used on those three courses. The result showed that the learning process in the three courses namely research methodology course in the department of sociology, Indian philosophy course in the department of Religious philosophy, and Arabic language course in the department of Arabic language education have used SCL approach in the learning process, even though with different strategies. Research methodology course in sociology department used guided teaching strategy, Indian philosophy course in Religious philosophy department used interactive learning strategy since that course emphasized discussion and sharing among the students, and
\end{abstract}


Arabic language course in Arabic language education department used peer lesson strategy, that was the students learned by teaching each other.

\author{
Kata kunci: \\ Strategi Pembelajaran, Student-Centered Learning, Perguruan Tinggi
}

LEMBAGA pendidikan merupakan ruang publik terjadinya lalu lintas pikiran, tempat berlangsungnya aktivitas akademik. Dalam hal ini, pengelola lembaga pendidikan hendaknya berusaha untuk memaksimalkan tujuan pendidikan, yakni bagaimana pendidik mampu merubah peserta didiknya menjadi lebih terampil, kreatif, bersahaja, berwawasan dan lain sebagainya. Namun, dalam merubah hal itu hendaknya dimulai dari pengelola lembaga pendidikan terlebih dahulu. Jika para pengelola lembaga pendidikan khususnya pendidik berusaha memberikan yang terbaik, maka perubahan pada peserta didik mengarah kepada yang lebih baik juga.

Pada proses perubahan menuju yang baik, provider pendidikan hendaknya juga memikirkan strategi yang tepat agar tujuan pendidikanya berjalan dengan baik tanpa terkendala apapun. Misal, menyangkut proses pembelajaran di kelas, pendidik sebaiknya mengatur strategi atau model pembelajaran yang bisa memberikan dampak positif bagi peserta didik agar peserta didik mampu mengeksplor kemampuan yang di miliki untuk menerima materi di kelas, karena bagaimanapun juga kelas merupakan jantung atau pusat dari proses peningkatan mutu di lembaga pendidikan.

Pada konteks lembaga pendidikan perguruan tinggi, sejatinya mahasiswa sudah mempunyai kedewasaan intelektual dan kritis dalam berfikir, kiranya dosen juga harus menentukan strategi pembelajaran yang tepat dan relevan sesuai konteks masa kini. Seperti yang di ketahui, masih banyak sebagian kampus di Indonesia dalam proses pembelajaranya menggunakan model pembelajaran teacher-learning center (TCL) atau pembelajaran yang berpusat kepada dosen/guru. Pembelajaran teacher centered learning (TCL) ini, pada dasarnya sudah tidak relevan lagi diterapkan karena membuat proses pembelajaran lamban dan mahasiswa tidak memiliki peluang untuk memilih menu yang sesuai. Kelambanan proses pembelajaran yang terjadi di dalam paradigma TCL akan menyebabkan peserta didik selalu tertinggal di belakang dan tidak dapat segera menyesuaikan diri dengan kemajuan zaman.

Seiring perkembangan zaman, untuk menyesuaikan kebutuhan mahasiswa dalam meningkatkan kualitas personalnya, pembelajaran student centered learning (SCL) muncul sebagai alternatif pendekatan pembelajaran untuk menjawab permasalahan ketidaksesuaian pendekatan TCL (Rasiban, 2013). SCL merupakan pendekatan pembelajaran yang berpusat pada peserta didik. Dalam pendekatan pembelajaran SCL, pendidik harus mampu melaksanakan perannya dengan baik yaitu tidak hanya sebagai pengajar, tetapi juga sebagai motivator, fasilitator, dan inovator. Pendidik tidak hanya dituntut untuk mengajar saja di depan kelas melainkan juga berperan membantu peserta didik untuk memecahkan masalah saat 
peserta didik mengalami kesulitan dalam proses pembelajaran. Natawijaya dalam (Depdiknas, 2003) menyebutkan bahwa belajar aktif adalah suatu sistem belajar mengajar yang menekankan keaktifan peserta didik secara fisik, mental intelektual dan emosional guna memperoleh hasil belajar berupa perpaduan antara aspek kognitif, afektif dan psikomotor.

Secara utilitas, pendidik/dosen memiliki peran yang penting dalam pelaksanaan pembelajaran di kelas, dosen hendaknya bertindak sebagai fasilitator dalam proses pembelajaran, mengkaji kompetensi mata kuliah yang perlu dikuasai mahasiswa di akhir pembelajaran, merancang strategi dan lingkungan pembelajaran yang dapat menyediakan beragam pengalaman belajar yang diperlukan mahasiswa dalam rangka mencapai kompetensi yang dituntut mata kuliah, membantu mahasiswa mengakses informasi, menata dan memprosesnya untuk dimanfaatkan dalam pemecahan permasalahan sehari hari, mengidentifikasi dan menentukan pola penilaian hasil belajar mahasiswa yang relevan dengan kompetensi yang akan diukur (Ramdhani, 2009).

Sehubungan dengan hal itu, agar secara ilustrasi kaitanya dengan pembelajaran berbasis student-centered learning itu dapat dipahami dengan jelas, maka penulis mengambil sebuah sampel penelitian di UIN Sunan Kalijaga Yogyakarta. Dalam hal ini, penulis mengamati proses pembelajaran pada tiga jurusan yang berbeda, yakni proses pembelajaran pada mata kuliah metodologi penelitian di jurusan sosiologi, mata kuliah filsafat India di jurusan filsafat agama dan pada mata kuliah bahasa Arab di jurusan pendidikan bahasa Arab. Penelitian ini bertujuan untuk mengetahui bagaimana proses pembelajaran berbasis SCL di masing-masing jurusan yang penulis amati, dan strategi pembelajaran apa yang digunakan oleh dosen dalam menyajikan materinya kepada mahasiswanya.

Berdasarkan uraian di atas, maka penulis akan menuangkan hasil penelitianya ke dalam sebuah artikel yang berjudul "Pembelajaran Berbasis Student-Centered Learning di Perguruan Tinggi: Sebuah Tinjauan di UIN Sunan Kalijaga Yogyakarta."

\section{METODE PENELITIAN}

Metode yang digunakan dalam penelitian ini adalah metode deskriptif dengan pendekatan kualitatif. Penggunaan metode dan pendekatan tersebut mengingat bahwa tujuan dari penelitian ini adalah untuk mendeskripsikan dan menganalisis tentang pembelajaran berbasis student-centered learning di perguruan tinggi. Lokasi yang menjadi obyek material dalam penelitian ini adalah kelas jurusan sosiologi, jurusan filsafat agama dan jurusan pendidikan bahasa Arab (PBA) jenjang S1 semester 7 UIN Sunan Kalijaga Yogyakarta. Waktu penelitian ini dilakukan pada tanggal 15 November 2017 di jurusan pendidikan bahasa Arab, tanggal 24 November 2017 di jurusan filsafat agama dan tanggal 29 November 2017 di jurusan sosiologi. Subjek dalam penelitian ini adalah dosen dan mahasiswa yang terlibat dalam proses pembelajaran di kelas. Penelitian ini, supaya mendapatkan data yang valid tentang pembelajaran berbasis student-centered learning di perguruan tinggi, peneliti 
menggunakan teknik pengumpulan data melalui observasi. Selanjutnya untuk menganalisis data yang telah dikumpulkan sejak awal penelitian sampai akhir penelitian dengan teknik reduksi data, penyajian data dan kesimpulan.

\section{HASIL PENELITIAN DAN PEMBAHASAN}

\section{Tinjauan Proses Pembelajaran}

\section{Pembelajaran Mata Kuliah Metodologi Penelitian di Jurusan Sosiologi}

Observasi dilakukan pada hari rabu, 29 November 2017, pada mata kuliah metodologi penelitian yang diampu oleh Bapak Riduan Zein. Pada pukul 10.30 mahasiswa memasuki kelas untuk mengikuti kegiatan perkuliahan, beberapa saat kemudian dosen juga datang dan memulai proses kegiatan perkuliahan. Di awal kegiatan perkuliahan, dosen meminta kepada mahasiswa untuk mengingat atau mereview kembali materi pertemuan sebelumnya yang berkaitan dengan metodologi penelitian, kemudian beberapa mahasiswa mencoba menanyakan kembali materimateri pertemuan sebelumnya. Salah satu mahasiswa menanyakan terkait rencana penelitian skripsinya yang yang berkaitan dengan internalisasi nilai-nilai religius di SMA 5 Yogyakarta, kemudian dengan penuh perhatian dosen memberikan solusi dan jawaban dari pertanyaan mahasiswa tersebut.

Setelah dirasa tidak ada pertanyaan lagi, dosen membuka laptopnya untuk melanjutkan materi pada pertemuan ini tentang penelitian kualitatif dan kuantitatif, pada materi tersebut ia memaparkan perbedaan penelitian kualitatif dan kuantitatif dengan menggunakan slide powerpoint yang sudah dipersiapkan dan menggunakan $e$ learning. Dalam proses pembelajaran, dosen memaparkan materi dengan sangat komprehensif dan detail. Sangat lumrah, jika mahasiswanya memperhatikan dengan seksama dan hanyut menikmati proses perkulahan tersebut. Namun, tak lupa di selasela proses perkuliahan dosen juga menyelingi dengan canda tawa agar proses perkuliahan lebih asyik dan menarik. Salah satu hal yang bisa ditangkap dari perkuliahan ini yaitu bahwa unsur utama yang harus diperhatikan dalam penelitian kualitatif adalah kedalaman informasi dari suatu objek yang akan kita teliti dan dikaji, sehingga diperlukan informan yang benar-benar relevan.

Sebagaimana dosen pada umumnya, setelah memaparkan materinya, ia memberikan kesempatan kepada mahasiswanya untuk bertanya. Setelah beberapa saat, salah satu mahasiswa ada yang bertanya mengenai bagaimana cara mendapatkan informasi yang representatif dan mendalam dari narasumber. Melalui pertanyaan tersebut, dosen terlebih dahulu memberi waktu dan kesempatan pada mahasiswa lain untuk menanggapi. Salah satu mahasiswa lain ada yang menanggapi, mahasiswa tersebut menjelaskan bahwa informasi dari narasumber merupakan data yang sangat utama, narasumber yang akan kita cari informasinya sebaiknya yang memiliki keahlian dalam bidangnya. Dosen juga menanggapi bahwa hal yang paling substansial agar mendapatkan data yang representatif yaitu salah satunya dengan indeep interview, dengan menggunakan panduan wawancara, agar memudahkan mendapatkan informasi. 
Berdasarkan uraian tersebut, dapat disimpulkan bahwa proses pembelajaran metodologi penelitian pada jurusan sosiologi termasuk pembelajaran berbasis studentcentered learning, karena ada aktifitas dua arah antara dosen-mahasiswa atau mahasiswa-dosen, dosen mengawali perkuliahan dengan meminta mahasiswanya untuk mereview materi pertemuan sebelumnya dan beberapa dari mahasiswa ada yang bertanya. Hal ini menunjukan bahwa terdapat pembelajaran partisipasif yang berorientasi kepada peserta didik, terlihat dari mahasiswa mencoba untuk aktif dengan mengajukan pertanyaan-pertanyaan kepada dosen, dan ada juga yang mencoba mengemukakan pendapatnya.

Pembelajaran berbasis SCL yang dilakukan pada jurusan sosiologi ini menunjukan bahwa dosen bukan sebagai titik konvergensi dalam setiap proses pembelajaranya. Namun, dalam proses ini dosen mampu berinisiasi untuk saling bertukar pikiran kepada mahasiswa, dosen mampu menghadirkan dirinya seolaholah sebagai teman mahasiswa. Oleh karena itu, mahasiswa seakan-akan tak segan untuk bertanya bahkan menanggapi materi apa yang di sampaikan oleh dosen. Di samping itu, jika merujuk pada pendapat (Sanjaya, 2007), dalam asumsinya mengenai proses pembelajaran, proses pembelajaran pada jurusan sosiologi ini menunjukan proses pembelajaran yang berorientasi pada peserta didik, karena di dalamnya ada peristiwa interaksi antara peserta didik dengan pendidik.

Selanjutnya, strategi pembelajaran berbasis SCL yang digunakan pada perkuliahan metodologi penelitian di jurusan sosiologi ini adalah strategi pembelajaran interaktif dan pengajaran terbimbing (guided teaching), karena dalam prosesnya, antara dosen dan mahasiswa saling berinteraksi dengan mengemukakan pendapatnya secara timbal balik. Dalam hal ini, bisa dilihat ketika dosen meminta mahasiswanya mereview materi pertemuan sebelumnya, beberapa mahasiswanya ada yang mencoba mengemukakan gagasanya, dan ada juga yang bertanya, lalu dosen mencoba menanggapi gagasan-gagassan yang dikemukakan oleh mahasiswa tersebut.

Selain itu, menurut hemat penulis dosen tidak hanya bertindak memindahkan pengetahuan dari pendidik kepada peserta didik, melainkan dosen memberikan kesempatan kepada mahasiswanya untuk membangun sendiri pengetahuanya. Jadi, dosen mata kuliah metodologi penelitian di jurusan sosiologi ini sudah menerapkan SCL karena dosen tersebut memposisikan dirinya seperti mahasiswa, yang mana hakikat mendidik berarti berpartisipasi secara langsung dengan peserta didik dalam membentuk pengetahuan, membuat makna, mencari kejelasan, bersikap kritis dan mengadakan justifikasi. Seperti yang dikemukakan oleh Martinis Yamin bahwa mendidik adalah suatu bentuk dari belajar sendiri (Yamin, 2007).

Dengan demikian, pada proses pembelajaran berbasis SCL pada jurusan sosiologi terdapat perpaduan antara metode ceramah dan diskusi dengan menekankan agar mahasiswa telah belajar secara mandiri sebelum masuk kelas, pembelajaran juga tidak dilakukan satu arah. Jadi, metode pengajaran yang dilakukan dosen bukan metode ceramah atau diskusi saja, tetapi gabungan dari 
keduanya. Dosen menyampaikan materinya dengan bantuan LCD projector, sedangkan mahasiswa diberi penjelasan materi dan diminta untuk menjelaskan bagian dari isi materi yang disampaikan dosen tersebut. Dengan demikian, akan terjadi dialog antara mahasiswa dengan dosen. Mahasiswa diberi kesempatan seluasluasnya untuk menyampaikan pendapat, bertanya atau mengkritik/berbeda pendapat, dan harus selalu siap sedia menjawab pertanyaan yang dilontarkan dosen.

\section{Pembelajaran Mata Kuliah Filsafat India di Jurusan Filsafat Agama}

Proses pembelajaran yang diamati kali ini dilakukan pada hari Jum'at, 24 November 2017, pada mata kuliah filsafat India yang diampu oleh Bapak Usman. Kuliah dimulai pada pukul 12.40, yang mana saat itu beberapa mahasiswa sudah ada di dalam kelas untuk mempersiapkan presentasi. Namun, beberapa mahasiswa yang lain masih ada yang di luar kelas mengobrol dengan temanya dan ada juga yang sibuk bermain handphone sambil menunggu dosen datang. Tidak lama kemudian pada pukul 12.50 dosen memasuki ruang kelas, bersamaan juga dengan mahasiswa yang tadi asyik di luar kelas.

Dosen mengawali perkuliahan dengan salam lalu meminta kepada mahasiswanya yang mendapat tugas presentasi untuk maju ke depan kelas. Tidak lama kemudian presentasi dimulai dengan materi yang akan disampaikan yaitu mengenai Filsafat India, di dalam pemaparanya mahasiswa menjelaskan bahwa sumber dan keterangan mengenai dunia dan manusia terdapat dalam kitab yang disebut kitab Veda. Veda berasal dari bahasa Sansekerta Vid yang artinya pengetahuan. Orang India menganggap bahwa isi kitab Veda diwahyukan oleh dewa tertinggi kepada para Mahasipara Guru. Apa yang telah dierima oleh para Mahasipra Guru itu diteruskan secara lisan berabad-abad lamanya kepada generasi-generasi selanjutnya. Kemudian mulai dibukukan sejak 2000 SM sampai dengan 500 SM secara bertahap, mulai dari Veda Samhita, kemudian Veda yang disebut Brahmana dan kemudian Veda yang disebut Upanisad.

Seiring berjalanya proses pembelajaran, ada sekitar 6-8 mahasiswa seringkali bergantian keluar masuk kelas, ada juga yang tidak memperhatikan materi yang disampaikan namun perhatianya tertuju pada layar handphonenya, namun tidak sedikit juga mahasiswa yang perhatianya tertuju materi yang disampaikan. Setelah pemateri selesai memaparkan materinya ternyata tidak banyak juga mahasiswa yang bertanya dan menaggapi materi yang disampaikan, tak lebih dari 3 mahasiswa yang bertanya, salah satu mahasiswa yang bertanya mengenai apa isi di dalam kitab Veda Brahmana, pemateri kemudian menjawabnya dengan menjelaskan bahwa isi yang ada di dalam kitab Veda Brahmana mengenai konsep dewa dalam menciptakan alam semesta, termasuk penciptaan manusia, hewan, tumbuhan dan lain-lain.

Presentasi selesai dan pembelajaran diambil alih oleh dosen dan kemudian dosen menjelaskan mengenai materi yang telah disampaikan oleh presentator tersebut. Sebelum mengakhiri perkuliahan dosen mengingatkan kepada 
mahasiswanya yang mendapatkan jatah presentasi minggu depan untuk mempersiapkan materi dengan baik.

Berdasarkan uraian tersebut menunjukan bahwa proses pembelajaran mata kuliah filsafat India pada juruasan filsafat agama menggunakan pembelajaran berbasis SCL atau pembelajaran berorientasi pada mahasiswa. Hal ini terlihat bahwa pembelajaran berorientasi mahasiswa terletak pada saat dosen meminta mahasiswanya yang mendapatkan tugas presentasi untuk memaparkan materinya kepada teman-teman sekelasnya. Dalam proses pembelajaran ini dosen hanya diam dan hanya memperhatikan jalannya diskusi, tanpa membantu atau bahkan mencoba mengarahkanya. Di samping itu dalam mendapatkan materinya, dosen menyuruh mahasiswanya untuk mencari bahan sendiri melalui literatur-literatur buku atau karya ilmiah orang lain untuk dijadikan rujukan. Ini membuktikan bahwa penerapan pembelajaran berbasis SCL sudah dilakukan meskipun keaktifan di kelas masih belum terlalu nampak, hanya ada beberapa mahasiswa yang berani mengemukakan pendapatnya dan bertanya. Dalam hal ini, mahasiswa antara mahasiswa saling berinteraksi, dengan adu gagasan mengenai materi yang sedang dibahas. Setelah presentasi berakhir baru dosen memberikan arahan lebih mendalam dan menjelaskan materi secara mendalam terkait materi yang dipresentasikan oleh mahasiswa.

Selanjutnya, strategi pembelajaran berbasis SCL yang digunakan pada mata kuliah filsafat India pada jurusan filsafat agama ini adalah strategi pembelajaran interaktif karena lebih menekankan pada diskusi dan sharing di antara peserta didik. Diskusi dan sharing memberi kesempatan peserta didik untuk bereaksi terhadap gagasan, pengalaman, pendekatan dan pengetahuan pendidik atau kawanya dan untuk membangun cara alternatif untuk berfikir dan merasakan.

Proses pembelajaran berbasis Student Centered Learning pada jurusan filsafat agama pada mata kuliah filsafat India ini bisa dibuktikan ketika dosen meminta mahasiswa untuk menyiapkan makalahnya bagi yang mendapatkan giliran presentasi. Ini menunjukan bahwa pembelajaran SCL ini bisa dimanfaatkan sebagai sumber belajar. Seperti yang kita ketahui bahwa setiap kampus mempunyai sarana prasarana penunjang pembelajaran, misalnya perpustakaan. Perpustakaan yang ada di kampus ini mempunyai utilitas sebagai tempat rekreatif peserta didik untuk mencari referensi ketika mahasiswa mendapatkan tugas dari dosen, selain itu perpustakaan ini juga berisi buku-buku yang dapat dibaca untuk mengisi waktu luang mahasiswa.

Di sisi lain, mahasiswa pada hakikatnya membangun pengetahuanya secara subjektif/mandiri. Kemandirian (self-direction) merupakan konsep organisasi untuk pendidikan tinggi dan kemandirian berkaitan erat dengan politik pendidikan. Pembelajaran mandiri memiliki komitmen demokratis terhadap perubahan posisi dan peran para mahasiswa, yakni mereka memegang kontrol yang lebih besar terhadap dirinya sendiri dalam hal konseptualisasi, perancangan, pelaksanaan, dan evaluasi belajar serta penetapan cara-cara pemanfaatan sumber belajar guna proses belajar lebih lanjut. Di samping itu, kemandirian selaras dengan perkembangan fisik, 
psikologik dan social mahasiswa yang masuk ke dalam alam dewasa. Secara ringkas dapat dikatakan bahwa kemandirian selaras dengan konsep adult-learner (Brookfield, 2002).

Dengan demikian, pembelajaran SCL bisa disebut dengan pembelajaran dewasa, karena menekankan mahasiswa untuk belajar dan membangun pengetahuan secara mandiri. Misalnya, ketika dosen memberikan tugas makalah, mahasiswa dituntut untuk mencari referensi atau bahan yang akan dijadikan makalah secara mendiri. Maka dari itu, hal ini salah satu bukti pembelajaran SCL sudah diterapkan pada jurusan filsafat agama di UIN Sunan Kalijaga Yogyakarta.

\section{Pembelajaran Mata Kuliah Bahasa Arab di Jurusan Pendidikan Bahasa Arab}

Pengamatan proses perkuliahan dilakukan hari Rabu, 15 November 2017, pada mata kuliah bahasa Arab yang diampu oleh Bapak Tulus Mustofa. Pada perkuliahan tersebut, dosen pengampu bahasa Arab tidak bisa hadir karena ada kepentingan menguji skripsi. Proses pembelajaran pada mata kuliah ini dimulai dengan presentasi yang dilakukan oleh mahasiswa, materi saat itu bertema metode pembelajaran bahasa Arab di Madrasah Ibtidaiyah, yang dibagi menjadi 3 subtema yang nantinya akan dipaparkan oleh 3 kelompok. Satu kelompok terdiri dari 3 mahasiswa, kelompok pertama membahas mengenai "pekerjaan/muhimmah", kelompok ke 2 membahas mengenai "al insyithot al yaumiyah/aktifitas sehari-hari", sedangkan kelompok ke 3 membahas mengenai "tarkib/susunan".

Di awali kelompok pertama, mahasiswa menyampaikan materi menggunakan model microteaching dilengkapi dengan LCD, mahasiswa yang berada di depan kelas seolah-olah sebagai guru lalu temanya yang duduk sebagai muridnya, pembelajaran kali ini sangat menarik karena dalam penyampaian kosa kata bahasa arab yang diucapkan presentator kemudian diikuti juga oleh temanya yang seolah-olah sebagai peserta didik. Misalnya, ketika mahasiswa yang di depan sebagai guru mengucapkan "mudarrisah" lalu mahasiswa lain sebagai muridnya mengikutinya dengan mengucap "mudarrisah". Begitupun dengan kelompok-kelompok berikutnya, dalam proses penyampaian materi tidak berbeda dengan penyampaian materi kelompok pertama.

Berdasarkan uraian tersebut, pembelajaran yang dilakukan pada matakuliah bahasa Arab di jurusan PBA menunjukan bahwa di dalam proses pembelajaranya menggunakan SCL. Terlihat pada hasil penelitian bahwa proses pembelajaran di kelas dari awal sampai akhir dikendalikan oleh mahasiswa, dalam pembelajaranya pun sangat berorientasi pada keaktifan mahasiswa untuk mengeksplor kemampuanya dalam menyampaikan materinya agar tersampaikan kepada kawankawanya. mahasiswa yang mendapatkan tugas presentasi seolah-olah menjadi seorang guru yang mengajar siswa MI, dan meminta kawan-kawan yang lain untuk mengikuti kosa-kata yang ia ucapkan.

Selanjutnya, strategi pembelajaran berbasis SCL yang digunakan pada mata kuliah bahasa arab di jurusan PBA ini adalah strategi pembelajaran peer lesson dan 
kolaboratif. Peer lesson yaitu pembelajaran dengan cara mengajar sesama teman, stretegi ini sangat baik digunakan untuk pembelajaran di kampus karena melatih mahasiswa untuk menjadi guru kepada teman-temanya. Dalam pembelajaran ini mahasiswa yang mendapatkan tugas presentasi diminta untuk menyampaikan materinya dengan cara mengajar seperti seorang guru dan teman-temanya yang lain sebagai siswa, sedangkan untuk pembelajaran kolaboratif secara teknis merupakan metode instruksional yang membuat mahasiswa dari berbagai macam latar belakang bekerjasama dalam kelompok kecil untuk mencapai tujuan pembelajaran secara umum. Berdasarkan pada konsensus yang dibangun sendiri oleh anggota kelompok, secara bersama-sama bertanggung jawab sepenuhnya atas proses pembelajaran yang mereka laksanakan. Dengan demikian keberhasilan seorang mahasiswa akan membantu keberhasilan kawannya (Gokhale, 1995).

Dengan demikian, bisa dikonklusikan bahwa pembelajaran yang dilaksanakan di jurusan PBA pada mata kuliah bahasa Arab secara kriteria termasuk dalam pembelajaran dewasa yang menekankan mahasiswa untuk selalu membangun pengetahuan secara kelompok dan berusaha semaksimal mungkin menyampaikan materinya kepada kawan-kawan sekelas. Jadi, dalam proses mencari sebuah materi mahasiswa PBA tersebut berkolaborasi kepada teman kelompoknya untuk menentukan strategi apa yang tepat untuk menyajikan materinya di kelas.

\section{Komparasi Pembelajaran pada Jurusan Sosiologi, Filsafat Agama dan Pendidikan Bahasa Arab}

Proses pembelajaran mata kuliah metodologi penelitan pada jurusan Sosiologi, mata kuliah filsafat India pada jurusan filsafat agama dan mata kuliah bahasa Arab pada jurusan PBA menunjukan bahwa proses pembelajaran pada setiap mata kuliah masing-masing menggunakan pembelajaran berbasis student-centered learning. Meskipun dalam penentuan strategi, setiap dosen menggunakan strategi yang berbeda, tetapi terdapat persamaan dari penggunaan strategi pembelajaran. Pada perkuliahan metodologi penelitian di jurusan sosiologi menggunakan strategi pembelajaran interaktif, yaitu pembelajaran yang menekankan keaktifan mahasiswa, yakni mahasiswa saling berdiskusi untuk mengemukakan pendapatnya dengan kawanya atau dosenya. Begitupun sebaliknya dosen juga memberikan pendapatnya terhadap materi-materi yang telah disampaikan. Perbedaan antara pembelajaran pada jurusan sosiologi dan filsafat agama itu terletak pada bentuk proses pembelajaranya. Pembelajaran pada jurusan sosiologi, dosen menempatkan dirinya sebagai sumber pengetahuan, yaitu dosen memimpin proses pembelajaran di kelas dengan memberikan kesempatan pada mahasiswa untuk aktif mengkritisi materi yang disampaikan dosen, sedangkan pada perkuliahan di jurusan filsafat agama, dosen meminta mahasiswa untuk menyampaikan materinya dengan presentasi, atau dengan kata lain bentuk pembelajaran pada mata kuliah ini yaitu dengan diskusi antar mahasiswa. Berbeda dengan pembelajaran di jurusan pendidikan bahasa Arab, perkuliahan tersebut berlangsung tanpa ada dosen yang mendampingi. Dengan 
demikian, dari awal sampai akhir kegiatan pembelajaran bahasa Arab di jurusan pendidikan bahasa Arab, proses pembelajaranya ditentukan oleh mahasiswa. Persamaan pembelajaran di jurusan pendidikan bahasa Arab dengan sosiologi dan filsafat agama sama-sama menggunakan SCL, tapi perbedaan strategi pembelajaran yang digunakan pada perkuliahan di jurusan pendidikan bahasa Arab sangat mencolok dibanding kedua jurusan sebelumnya, pada jurusan PBA mahasiswa mempunyai kesempatan untuk menjadi guru bagi kawan-kawanya. Jadi, dalam pembelajaran ini mahasiswa yang berperan menjadi seorang guru menyampaikan materi dengan model microteaching atau peer leeson.

Dengan demikian, pembelajaran yang dilaksanakan pada jurusan pendidikan bahasa Arab dapat disimpulkan bahwa microteaching atau pengajaran mikro adalah salah satu model pelatihan praktik mengajar dalam lingkup terbatas (mikro) untuk mengembangkan keterampilan dasar mengajar yang dilaksanakan secara sederhana.

Dalam pembelajaran berbasis SCL, tujuan umum pengajaran microteaching adalah untuk memberikan kesempatan kepada mahasiswa (calon guru atau dosen untuk berlatih mempraktikan beberapa keterampilan dasar mengajar di depan teman-temannya dalam suasana yang constructive, supportive, dan bersahabat. Dengan demikian, hal tersebut berimplikasi pada kesiapan mental, keterampilan dan kemampuan yang terintegrasi untuk bekal praktik mengajar sesungguhnya di sekolah/institusi pendidikan.

\section{SIMPULAN}

Pembelajaran berbasis student centered learning (SCL) merupakan metode yang dapat memfasilitasi peserta didik. Mahasiswa secara langsung ataupun tidak langsung dapat terlibat dalam proses pembelajaran. Dalam pembelajaran berbasis SCL, dosen menekankan kepada peserta didik untuk aktif dalam pembelajaran di kelas, karena pembelajaran semacam ini sangat substansial dan berperan penting dalam menstimulasi perkembangan kognisi peserta didik dan membantu peserta didik untuk meningkatkan SDMnya. Ada beberapa strategi pembelajaran yang bisa digunakan di perguruan tinggi untuk menekankan mahasiswa selalu aktif, antara lain strategi pembelajaran interaktif, pembelajaran kooperatif, pembelajaran timbal balik, pembelajaran kolaborasi dan sebagainya. Dengan demikian, pembelajaran berbasis SCL ini sangat baik dan memberikan kesempatan kepada peserta didik untuk mengeksplor kemampuanya yang dimiliki, bukan hanya tertuju pada kehendak pendidik atau dosen saja.

\section{DAFTAR PUSTAKA}

Brookfield. (2002). Self-directed Learning, Political Clarity and the Critical Practice of Adult Education. Adult Educ Quart, 43(4), 30.

Depdiknas. (2003). Pendekatan Kontekstual (Contextual Teaching and Learning. Jakarta: Ditjen Dikdasmen.

Gokhale. (1995). Collaborative Learning Enhances Critical Thinking. Journal Teach 
Educ, 7(1), 1045.

Harsono. (2008). Student-Centered Learning di Perguruan Tinggi. Jurnal Pendidikan Kedokteran dan Profesi Kesehatan Indonesia, 3(1), 5.

Kurdi, F. N. (2009). Penerapan Student-Centered Learning dari Teacher-Centered Learning Mata Ajar Ilmu Kesehatan pada Program Ilmu Kesehatan. Forum Kependidikan, 28(2), 109-110.

Ngalimun. (2011). Strategi dan Model Pembelajaran. Yogyakarta: Aswaja Preesindo.

Ramdhani, N. (2009). Ruh Experiential Learning dalam SCL. Retrieved from http:/ / neila.staff.ugm.ac.id/?pilih=lihat\&id=10.

Rasiban, Meilia, L. (2013). Penerapan Student-Centered Learning Melalui Metode Mnemonik Dengan Teknik Asosiasi Pada Mata Kuliah Kanji Dasar. Jurusan Pendidikan Bahasa Jepang FPBS UPI.

Sanjaya, W. (2007). Strategi Pembelajaran Berorientasi Standar Proses Pendidikan. Jakarta: Kencana.

Yamin, M. (2007). Strategi Pembelajaran Berbasis Kompetensi. Jakarta: Gaung Persana Press. 